\title{
CONSUMERS' ATTITUDE TO THE AIR PASSENGER DUTY IN THE UK - AN EXPLORATORY STUDY
}

Ema Tsvetanova

Bournemouth University

Neelu Seetaram (corresponding author)

University of Huddersfield

\begin{abstract}
This paper explores British consumers' knowledge, awareness, attitude and reaction to changes in the air passenger duty imposed on outbound air travel from the UK. Survey data were collected using an online survey. The key findings of this paper are that firstly, consumers are not aware of the amount of taxes they pay on air tickets and therefore, this may be limiting the ability for the taxes to influence behaviour. Secondly, increases in this tax will not discourage consumers to travel abroad but rather affect consumers' intention to finance such an increase by either reducing their consumption on tourism related products at the destination or by reducing their consumption of other products in the UK. Thirdly, there is an asymmetry in the response of consumers' reaction to increases in taxes as compared to reduction in taxes. These findings can form the basis for an in-depth study on consumer behaviour in the UK travel industry.
\end{abstract}

\section{KEYWORDS}

Tourism Taxes; APD; UK Outbound Tourism, Consumer Behaviour

Ema Tsvetanova is a graduate from Bournemouth University. She has studied for a degree in Tourism Management and is interested in aviation related issues.

Neelu Seetaram is an economist who has published several papers in the field of tourism demand modelling and edited two books. She is interested in the study of linkages between aviaiton and tourism and in modelling tourism demand. Email : $\underline{\text { n.seetaram@hud.ac.uk }}$ 


\section{INTRODUCTION}

Air Passenger Duty (APD) is an aviation tax that was introduced in the United Kingdom in 1994. The purpose of APD is outlined by Seely (2012) who cites Chancellor Kenneth Clarke's Budget Speech from 1993. In his speech Kenneth Clarke states that the aviation industry is undertaxed and therefore by introducing this tax, revenue can be raised without any significant consequence to the economy. Although it is true that the aviation industry does benefits from zero rate of VAT and pays no duty on fuel (Airportwatch 2014), APD is one of the highest aviation taxes levied in the world. The growing number passenger flows in the UK means that this tax is a very lucrative source of revenue for the government. Later government reports (UK Parliament 2003) state that the main purpose of the Air Passenger Duty is to raise revenue from the aviation industry and justifies its introduction in the UK with environmental benefits that the tax will bring. It was considered that these environmental benefits will come as a result of the tax negatively effecting air traffic volumes.

However, the number of departures from the UK has increased on average by $2 \%$ (Euromonitor 2014) and a recent study by Seetaram et al. (2014) indicates the ADP has only a marginal effect in reducing the number of outbound trips from the UK. It may be argued that consumers do not react to the tax by changing cutting down on number of trips taken but rather re-adjust their budget to absorb the amount of tax paid payable on an international trip. This study which is designed as a pilot study, postulates that consumers are unaware of the level of taxes paid and therefore, do not react to changes in this figure. The aim of this study, therefore, is to examine British consumers' knowledge, awareness, attitude and reaction to changes in the air passenger duty which in imposed on all outbound air travel from the UK, using survey data.

\section{RATIONALE FOR TAXING TOURISM}

Tourism as an economic activity involves the movement of people and vehicles, as well as the use of natural resources and infrastructures of the country visited (Chang et al. 2011). This inevitably imposes extra costs on governments that need to provide and maintain the necessary tourism infrastructure in order to sustain the economic benefits from the industry. These costs are often covered by local residents through revenue generated from taxes. This is where the classic argument for tourism taxation is drawn. According to Jensen and Wanhill (2002), tourism taxes address inequalities by placing the burden upon the ones responsible for generating the initial costs and therefore, affect domestic welfare positively. 
Another significant reason for imposing taxes on the tourist is to correct externalities (Gooroochurn and Sinclair, 2005). The term 'externality' is used by Schipper et al. (2001) to describe any consequences of an economic activity that affect unrelated third parties. One such externality which Tol (2007) carefully acknowledges is the environmental impact caused by the aviation industry. His research acknowledges the industry's high and growing level of carbon dioxide emissions and examines whether the imposition of a carbon tax would correct the externality. His work aims to determine the impact of a carbon tax on consumer demand and to assess whether this impact would reduce the environmental costs. With the use of a simulation model of international tourist flows, Tol (2007) determines that a global carbon tax such as Air Passenger Duty (APD) would affect consumer demand in a way that long-haul travellers would switch to medium-haul destinations and medium-haul travellers to short-haul destinations. Using his findings, Tol (2007) concludes that a global air travel tax of $\$ 1000 / t$ $\mathrm{CO} 2$ would change consumers' travel behaviour which will reduce carbon dioxide emissions from international aviation by $0.8 \%$. Tol's (2007) findings represent a valuable source of information for the researcher and will be further referred to in the following chapters. More recently, Seetaram et al. (2018) used survey data to show that consumers are willing to pay more for the ADP on long haul flights than for short haul fights and that the majority prefer the revenue to be used for projects related to the environment.

Going back to the rationale of taxing the tourism industry, the study by Gooroochurn and Sinclair (2005) uses the case of Mauritius to prove the efficiency and effectiveness of tourism taxation in improving domestic welfare. Their general equilibrium analysis indicates that revenue generated through the tourism sector decreases government's dependency on other taxes paid by residents of the country. The study directly links to the final rationale of taxing the tourism industry- the exportability of the tax. On one hand, international tourism is a service export (Sheng and Tsui 2009). Therefore, by taxing different tourism services, taxes are exported, and revenue is generated from non-residents. As the tax burden falls on nonresidents, the effect of tourism taxation has little effect on domestic welfare (Gooroochurn and Sinclair 2005). On the other hand, however, studies conducted by Fish (1982) question the extent to which tourism taxes can be exported. In his research, he points out that the degree of exportability largely depends on the price elasticity of demand (PED). In other words, if the consumer is price sensitive, businesses absorb a proportion of the tax in order to retain market share. If a proportion of the tax is absorbed by businesses however, this would reduce their revenue and force them to review their expenses in order to close the gap. One way to close this gap might be to reduce the number of staff employed. Therefore, even 
though tourism taxes are considered to export tax, the more elastic the demand (i.e. the more price sensitive the consumer), the more the tax burden would fall upon businesses and residents of the country, rather than on the tourists (Fish 1982). The following sections explore the effects of tax and price elasticities in further detail.

\section{THE EFFECTS OF TAXES}

In order to better understand the benefits and threats to tourism taxation; it is important to note that tourism taxation is a form of government intervention in the market. Taxes have the effect of raising marginal costs of production. Depending on external factors, suppliers might wish to keep their prices low and absorb the full tax without placing a burden on the consumer. They might also decide to cover the tax partially by slightly increasing their prices or shifting the entire tax burden to the consumer by incorporating the tax' full amount in their prices.

Taxation may not be a serious issue where the market power is strong (Sheng and Tsui 2009). However, imposing a tax in a highly competitive environment may pose a threat to the economy. Fish (1982) puts forward a study on West Africa's accommodation sector. In his work he argues that intense competition in the area and price sensitivity of consumers have led businesses to absorb the tax on hotel bed nights with some businesses having to leave the industry. This is one example of how despite governments exporting the tax, a tourism tax can still cause distortion in an economy. On the other hand, Gooroochurn and Sinclair's study (2005) of Mauritius show how tourism taxes are in fact beneficial for the host country. The above two studies prove Jensen and Wanhill's (2002) argument that a tourism tax's impact differs from a country to a country and largely depends on the linkages between the country's tourism industry and the rest of its economy. Authors such as Millet (1987) also stress on the importance of the industry's lifecycle. During tourism's development stage, Millet (1987) argues, leakages from the industry abroad are likely to be high, therefore reducing the welfare effects of tourism taxes. There are different ways in which the effects of tourism taxes can be looked at (Sheng and Tsui 2009; Jensen and Wanhill 2002). However, academic opinions seem to reach an agreement. Looking at the economic effects, according to Sheng and Tsui (2009) tourism taxes reduce a destination's welfare in accounting terms. Effects might be seen in the form of a shrinking Gross Domestic Product (GDP). Despite certain economic costs that may occur, there is evidence that the total welfare of a destination can still increase (Sheng and Tsui 2009). To summarise the literature suggests that tourism 
taxation effects depend largely on the country's market power and the price sensitivity of the consumer.

International tourism is a service export used by destinations to finance imports of other goods and services (Sheng and Tsui 2009). In the beginning of the 1960s the industry is considered to be largely free of tax (WTO 1998). However, in recent years both the number of tourism taxes and their level have been expanding with many organisations and academics expressing their concerns (WTO 1998). Authors including Gooroochurn \& Sinclair (2005) and Jensen \& Wanhill (2002) point out how tourism taxes have become a target for governments. The rate at which tourism taxes have been increasing both in number and in level have generated a debate around the topic of whether tourism taxes are economically rational (Sheng and Tsui 2009). Looking at the United Kingdom, there is a particular tourism tax that directly links to the concerns outlined above.

\section{AIR PASSENGER DUTY}

Introduced in 1994, Air Passenger Duty (APD) is an air travel tax. As such, APD's main purpose is like the one of all tourism taxes. Its aim is to raise revenue for the UK economy through the tourism sector. The tax applies to all passenger flights departing from any UK airport, travelling both domestically and internationally. The level of tax varies depending on the class of travel and the destination travelled to. Since its introduction in 1994, APD has been reformed 8 times to reach its current scope and levels. For the financial year 2013/ 2014 APD has generated $£ 3.0$ billion to the UK economy (Seely 2014). Table 3 presents Air Passenger Duty's steep rate increase throughout the years. Starting at just $£ 5$ for Economy and $£ 10$ for Business class passengers, the tax has also developed in a way to distinguish between short-haul and longhaul travellers imposing a higher rate for the latter.

Being one of the highest aviation taxes levied in the world, APD has become a controversial subject. With its constant growth over the past years, the APD discussion can be linked to Sheng and Tsui's (2009) concerns on how economically rational tourism taxes are. Businesses have also raised concerns over the tax's effectiveness and its impacts on the economy with most opinions considering the tax as unfair (PwC 2013). This has led to government's decision to proceed with another reform of the tax. The major changes include abolishing Bands $\mathrm{C}$ and D, as well as scrapping the tax for children under the age of 12 (Smith 2014). Changes came into practice in April 2015. Apart from raising revenue for the UK economy, APD has also been justified as a tourism tax that would have positive impact on the environment. According to 
the UK Parliament (2003), APD was expected to impact negatively the number of people travelling abroad. This belief was based on the law of demand according to which increases in price have a negative effect on demand. However, whether this has been the case is debatable. The following section examines in further detail.

Table 1 - Evolution of the ADP in the United Kingdom

\begin{tabular}{|c|c|c|c|c|c|c|c|c|c|}
\hline $\begin{array}{l}\text { Date of } \\
\text { Change }\end{array}$ & \multicolumn{4}{|c|}{$\begin{array}{ll}\text { Reduced } & \text { Rate } \\
\text { (Economy Class Travel) }\end{array}$} & \multicolumn{5}{|c|}{$\begin{array}{lr}\text { Standard } & \text { Rate } \\
\text { (Business Class Travel) }\end{array}$} \\
\hline 01.11 .94 & \multicolumn{4}{|l|}{5.00} & \multicolumn{5}{|l|}{10.00} \\
\hline 01.11 .97 & \multicolumn{4}{|l|}{10.00} & \multicolumn{5}{|l|}{20.00} \\
\hline $\begin{array}{l}\text { Date } \\
\text { Change }\end{array}$ & \multicolumn{2}{|c|}{$\begin{array}{l}\text { EEA } \\
\text { Destinations }\end{array}$} & \multicolumn{2}{|c|}{$\begin{array}{l}\text { Non-EEA } \\
\text { Destinations }\end{array}$} & \multicolumn{2}{|c|}{$\begin{array}{l}\text { EEA } \\
\text { Destinations }\end{array}$} & \multicolumn{3}{|c|}{$\begin{array}{l}\text { Non-EEA } \\
\text { Destinations }\end{array}$} \\
\hline 01.04 .01 & \multicolumn{2}{|l|}{5.00} & \multicolumn{2}{|c|}{20.00} & \multicolumn{2}{|l|}{10.00} & \multicolumn{3}{|c|}{40.00} \\
\hline 01.02 .07 & \multicolumn{2}{|l|}{10.00} & \multicolumn{2}{|c|}{40.00} & \multicolumn{2}{|l|}{20.00} & \multicolumn{3}{|c|}{80.00} \\
\hline \multicolumn{10}{|c|}{ 'EEA' and 'Non-EEA' Categories are abolished. Introduction of a Four Band System } \\
\hline \multirow[t]{2}{*}{ Date } & \multicolumn{4}{|c|}{$\begin{array}{l}\text { Reduced } \quad \text { Rate } \\
\text { (Economy Class Travel) }\end{array}$} & \multicolumn{5}{|c|}{$\begin{array}{lc}\text { Standard } & \text { Rate } \\
\text { (Business Class Travel) }\end{array}$} \\
\hline & $\begin{array}{l}\text { Band } \mathbf{A} \\
0-2,000 \\
\text { miles }\end{array}$ & $\begin{array}{l}\text { Band } \\
\text { B } \\
2,001- \\
4,000 \\
\text { miles } \\
\end{array}$ & \begin{tabular}{|l} 
Band \\
C \\
$4,001-$ \\
6,000 \\
miles \\
\end{tabular} & $\begin{array}{l}\text { Band } \\
\text { D } \\
\text { Over } \\
6,000 \\
\text { miles } \\
\end{array}$ & $\begin{array}{l}\text { Band A } \\
0 \\
2,000 \\
\text { miles }\end{array}$ & $\begin{array}{l}\text { Band E } \\
2,001- \\
4,000 \\
\text { miles }\end{array}$ & & $\begin{array}{l}\text { Band } \\
\text { C } \\
4,001- \\
6,000 \\
\text { miles } \\
\end{array}$ & $\begin{array}{l}\text { Band } \\
\text { D } \\
\text { Over } \\
6,000 \\
\text { miles } \\
\end{array}$ \\
\hline 01.11 .09 & 11.00 & 45.00 & 50.00 & 55.00 & 22.00 & 90.00 & & 100.00 & 110.00 \\
\hline 01.11 .10 & 12.00 & 60.00 & 75.00 & 85.00 & 24.00 & 120.00 & & 150.00 & 170.00 \\
\hline 01.04 .12 & 13.00 & 65.00 & 81.00 & 92.00 & 26.00 & 130.00 & & 162.00 & 184.00 \\
\hline 01.04 .13 & 13.00 & 67.00 & 83.00 & 94.00 & 26.00 & 134.00 & & 166.00 & 188.00 \\
\hline 01.04 .14 & 13.00 & 69.00 & 85.00 & 97.00 & 26.00 & 138.00 & & 170.00 & 194.00 \\
\hline 01.04 .15 & 13.00 & 71.00 & - & - & 26.00 & 142.00 & & - & - \\
\hline
\end{tabular}

Compiled by authors

\subsection{Effects of APD on Inbound and Outbound Travel}

The discussion previously held has led to the conclusion that travel taxes can both improve the domestic welfare of a country, but they can also cause distortions in the economy. Revenue generated from tourism can be either linked back to the industry (Jansen \& Wanhill 2002), or used to finance projects and support government expenditure without imposing a burden upon residents. Looking closely at APD however, the revenue generated from the tax 
is gathered from incoming travellers, but also from UK residents travelling abroad. Figure 1 illustrates the tourism flows to the UK for the period 1980 - 2013. The first observation made is that there is a widening gap between inbound and outbound tourism levels. It is argued that in the Post Brexit era with a sharp depreciation in the British Pound this gap may narrow as UK becomes more affordable as a destination for tis main market and outbound travel become more expensive for British travellers. With air transport being a preferred method of travel for outbound travellers (Euromonitor 2014), it could be argued that a larger percentage of APD revenue is gathered from UK residents and once again raises Fish's concern (1982) whether the tax is exportable.

As a comparison to APD, this study considers the Passenger Movement Charge-a departure tax in Australia that is like APD. According to research conducted by Forsyth et al. (2014) the tax raises costs of travel for inbound tourists and therefore reduces the number of visits to the country. Although the Passenger Movement Charge is proved to have some positive economic impacts on GDP, employment and economic welfare, through an increase in domestic travel, these are offset by a drop in visitation numbers to the country due to rising air travel prices. Looking at Air Passenger Duty in the UK, Mayor and Tol (2007) stipulate that the doubling of the tax in 2007 would lead to a slight decrease in passenger arrivals to the UK, as consumers are in fact price sensitive and would switch their travel destination. Seetaram, Song and Page (2014) state that although the APD leads to a decline in the number of outbound trip from eh UK, the effect is fairly small, thus negating any potential gains in term of reduction in emission related to air travel.

Song, Seetaram and Ye (2019) find that travellers account for the increase in cost of their international trip, resulting from the APD, by reducing their expenses at the destination. Durbarry's (2008) gravity model draws upon the same conclusion after modelling inbound tourism demand in the UK. Looking at data from recent tourism statistics however (ONS 2013), the factual information contradicts both Mayor and Tol's (2007) and Durbarry's (2008) opinion on the effects of a rising departure tax such as APD. As Figure 1 shows, inbound tourist arrivals have been steadily rising only to reach 32.8 million visits in 2013- an increase of $164 \%$ from 1980. The upward trend in visitor arrivals has been disrupted twice following the $9 / 11$ attacks in the US in 2002 and the 2009 financial crisis. 


\section{Figure 1 - Tourism Flows in the UK}

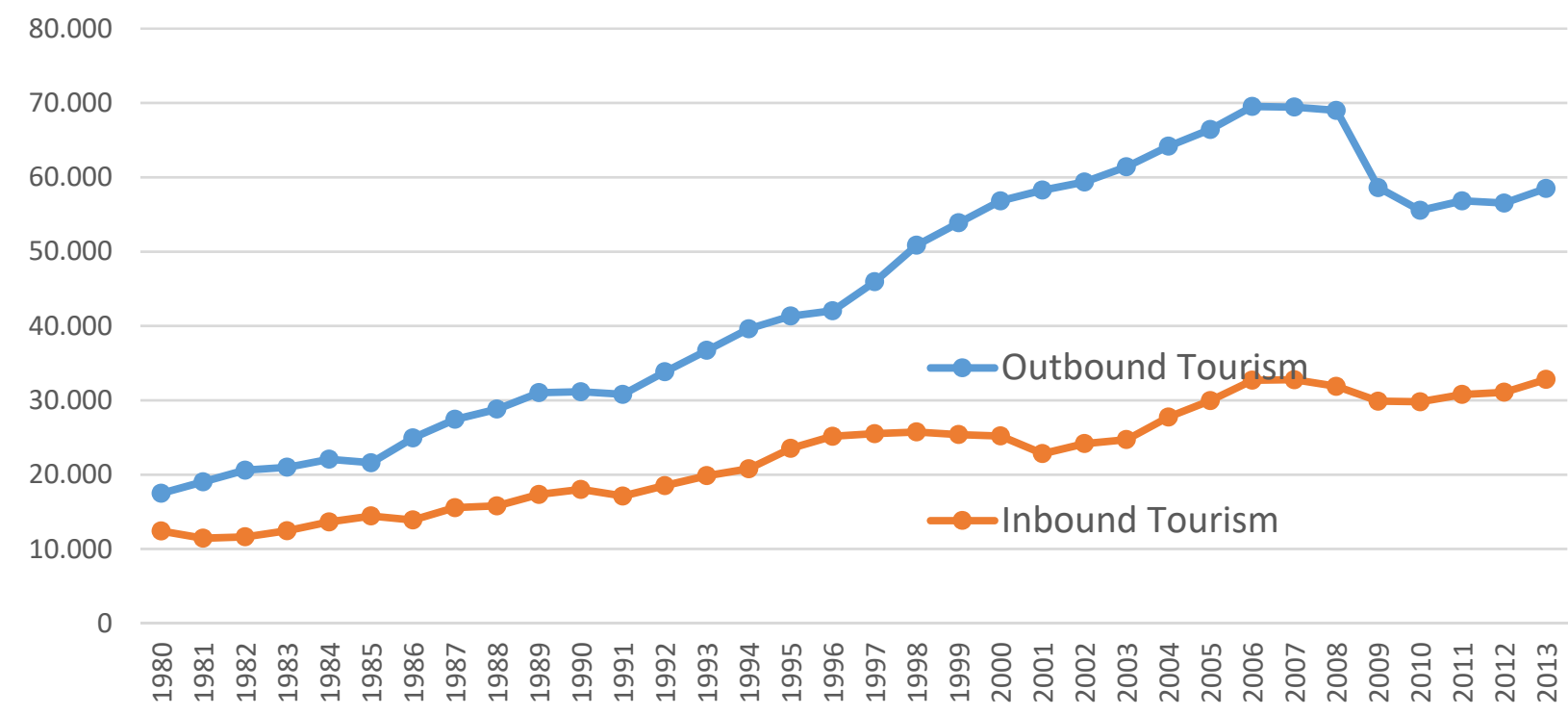

Complied by authors using data from Office of National Statistics, UK.

The study of Passenger Movement Charge (PMC) draws upon the conclusion that despite rising departure taxes, Australian residents would pay higher prices to travel overseas (Forsyth et al. 2014). Even though a small percentage of outbound travel demand would be offset due to higher air fares, Forsyth et al. (2014) claim that rising tax would set an increase in domestic travel. When looking at the effect that APD is considered to have on outbound travel, it is estimated that fewer people would travel to nearby countries, however the level of people travelling mid and long-haul would increase (Mayor and Tol 2007). According to Mayor and Tol (2007) this is due to the departure tax raising short-haul ticket prices relatively more compared to the increase in prices for mid and long-haul flights. Going back to Figure 1, between 1980 and 2013, outbound travel from the UK has witnessed an increase of 230\%. The biggest drop in outbound tourism is witnessed during the 2009 economic crisis which has led to a record fall in the value of the sterling (Smith 2008) and higher air fares due to costs of fuel (Rhodes 2015). Despite the 2009 economic crisis however, outbound tourism levels have continued to grow as seen in Figure 1. Following the figures and discussions above, it can be concluded that despite the increasing levels of APD, both inbound, as well as outbound tourism levels continue to increase. The following section will try to understand consumer awareness, attitude and reactions to the APD in order to understand the low marginal effect of this tax. 


\section{METHODOLOGY}

Given this research is intended as a pilot study which aims at providing insights into consumer behaviour to design a major in-depth study on consumer behaviour in the air travel industry, it was deemed appropriate to collect data using an online survey. According to Bryman (2012), this method is adequate when the study is limited by time and finance which is the case here. Furthermore, online surveys are useful for obtaining data from a wide geographic spread of (Sue and Ritter 2007). The limitation however as Jennings (2001) points out is that it may pose a threat of alienation of participants that do not have an online presence.

\subsection{Questionnaire Design}

The survey is structured to reflect central themes derived from the literature (Dwyer, Gill and Seetaram, 2012). Section 1 relates to personal information about participants. It forms a profile of the respondents and provided valuable information for the researcher to structure different market segments based on income, age, type of traveller, nationality. This would allow the researcher to compare the level of APD knowledge between different categories. It would also enable the researcher to look at separate market segments and assess different segments' behavioural response to changes in APD.

Section 2 attempts to examine consumers' actual travel behaviour by questioning participants about their last international experience. This enables easier recollection of information and quicker question completion, as it relates to an actual experience (Finn et al. 2000). Openended questions eliminate the threat of limiting participants to a set of options. Questions distinguish between long, medium and short-haul travellers. They establish participants' purpose of travel and determine their relationship concerning the booking (i.e. whether it was a personal booking, direct booking etc.) while further shaping consumer profiles.

Section 3 is regarded as most valuable section of the survey. It generates data linked directly to the subject researched - tourism taxes and APD. The section provides a simple introduction of APD in order to set the background. The section proceeds to examining participants' attitude towards APD and their opinions regarding the purposes of the tax. The final question puts participants in hypothetical situations where APD's levels were increased or decreased. The statements used reflect the main points previously derived from the literature and research the effect that changes in APD have on participants' travel behaviour. 


\subsection{Data Collection and Sample Description}

The link to the online questionnaire was made public predominately through email and social media due to the viral nature of the two (Sue and Ritter 2007) in February 2015. A snowball technique was developed to increase the sample size and strengthened the penetration amongst the population. After rejecting questionnaire that could not be used, the sample size for this study is 112 . The limitation of the study, however, is that the sample is favours those who have access to the internet and are regular users. This explained the higher proportion of younger people in the sample with $56 \%$ aged between 18 and 24 . The remaining $44 \%$ however, represents a suitable number of participants from the other age groups. Results confirm Jennings's (2001) concern of online surveys alienating participants who do not have an online presence, as only $2 \%$ of respondents fall under the ' $65+$ ' age group suggesting their inability to access the survey. This is furthermore reflected in income level of the sample. For example, Thornton et al. (1997) suggest, there is a connection between the age and income which may explain why $42 \%$ of people surveyed fall under the 'Less than $£ 19,999$ ' annual income, 23 percent of the respondent earned over than $£ 50,000$ per year.

It is likely that the degree of exposure to the taxes will influence consumers' level of knowledge and awareness of these taxes and this in turn will influence their behaviour towards them. Therefore, for the purpose of this research, it is regarded as necessary to establish the degree to which participants are directly affected by APD. Questions aim to establish the background of participants by researching their nationality and their place of residence for the past 3 years. The results indicate that 55 percent of the respondents are British Citizen. However, 69\% has been living in the UK in the past 3 years. $61 \%$ had travelled abroad from the UK at from 1 to 5 times in the past 5 years. $87.5 \%$ of these trips were by air. This is in line with secondary data obtained from Euromonitor (2014).

Figure 2 - Frequency of Outbound Travel in the past 3 Years

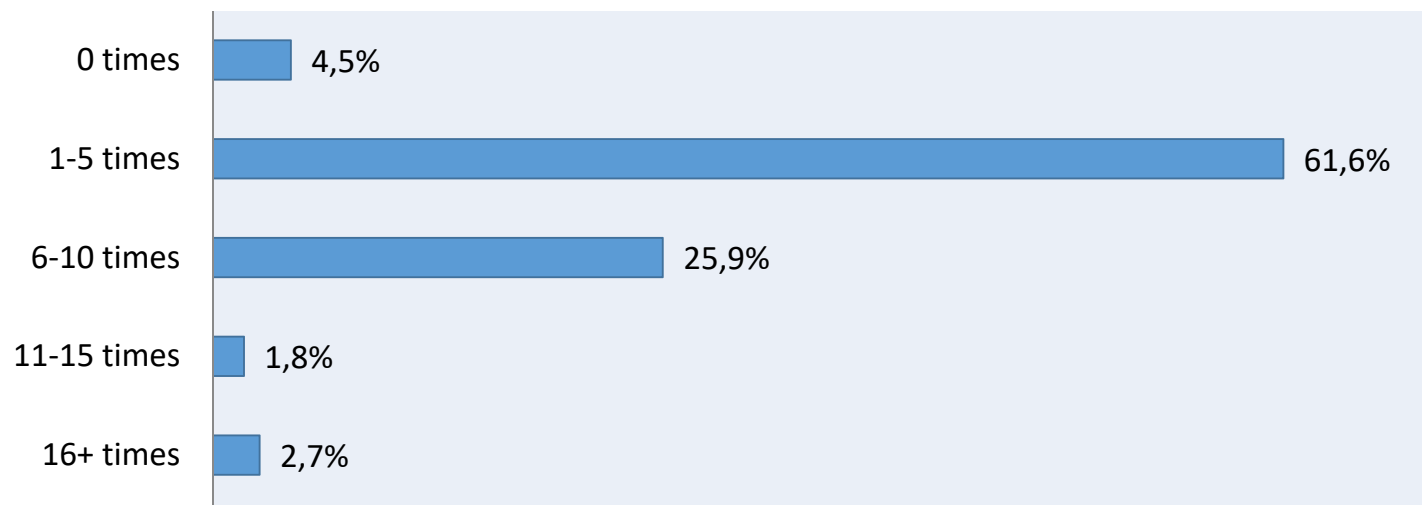


The data revealed that travellers were taking frequent short trips, as those who flew more than 5 times were more likely to have travelled to a Band A destination. $71 \%$ of the destinations flown to fall under APD's Band A. This could suggest certain degree of price sensitivity on behalf of participants (Smyth and Pearce 2008). It is not surprising as only 10.7 $\%$ of the travellers were on business trip. According to Dresner (2006), business travellers are the least price sensitive customers. However, data suggests that most international trips were undertaken on a low-cost carrier (47\%), 43\% travelled on full-service airlines and the remaining on charter flights.

\section{RESULTS OF THE EMPIRICAL STUDY}

\subsection{Knowledge of Taxes Paid}

Participants were asked question specific to taxes that they would have incurred during their trip to try to understand their level of knowledge and awareness of such taxes. Note that questions were specific about taxes and other charges were not considered. Only $29.5 \%$ of respondents knew that a tax had been levied on their tickets. 59.8\% replied they did not know whether a tax has been levied or not while $9.8 \%$ replied no taxed has been charged. Only $20.5 \%$ believe they had paid any taxes during the whole trip including at the destinations. $37.5 \%$ believe that they did not pay any taxes during the trip although travellers to Europe would have incurred bed taxes and VAT or other forms of value added taxes on their consumption in the UK and abroad during the trip. These results are consistent across the income levels and irrespective of type of carrier used. However, most of the respondents agree that they will be interested in knowing the extent of the taxes that they have incurred on their trip including taxes paid at the destination. The next section focuses on the Air Passenger Duty.

\subsection{Awareness of the APD}

Despite the media coverage and campaign about the APD from both the government and industry, during the data collection period, only $37 \%$ of the respondents have some knowledge of the APD. Overall, participants indicate a reasonable level of knowledge regarding the structure of the tax. Of those, $55.4 \%$ know that the APD is a tax charged on international flights. Although the consumers surveyed believe that the level of APD is the same for both low-cost and full-service carriers (41.1\%), they (28.6\%) believe that business and economy 
classes are charged at the same rate which is not the case. Responses show a general awareness of the tax's reforms over the years with $22.3 \%$ believing that several changes took places since 1994 although in general they are not able to correctly name these changes. Amongst the purposes of introducing APD, respondents believe the tax is used to generate government revenue $(41.1 \%)$, pay government debts $(25.9 \%)$ and finance environment related projects (27.7\%). Respondents do not believe the purpose of the tax is to discourage people from travelling (49.1\%). In reality, this tax is an important source of revenue generation for the government and the exact used of the tax is not known. It is believed the revenue is used to finance public expenses and may or may not be financing tourism-related or environmental projects. The nature of the usage of the taxes, however, seem to matter for the consumers. As seen in the next section.

\subsection{Attitude towards APD}

The attitude of the consumers towards the APD is examined in this section. $59 \%$ of respondents agreed that it was fair to tax air travel. In fact, only $15 \%$ of respondent agreed that it was not justified to impose taxes on air travel. Willingness to pay depended on the purpose of the tax with a high percentage expressing an interest in knowing how the tax revenue will be used (54.5\%). Respondents with income level of 20,000 and higher are even more eager to know more about the usage of the tax revenue. $41.1 \%$ of the respondents agree that the tax revenue be used for tourism related projects. There is however a marked difference between the responses of low-cost airlines with only $30.8 \%$ agreeing that it was justified to use airline taxes to raise revenue for tourism related project compared to $56.6 \%$ for travellers of full cost airlines. These results varied by income levels of the respondents. $53.3 \%$ of income level of respondent with income of up to $£ 19,999$ disagree the tax revenue be used to finance tourism related project as compared to only $28 \%$ of respondents with income of $£ 20,000$ and above who disagree with the same.

Financing environmental project was the more popular option for the usage of the tax revenue. $45.5 \%$ of respondents agreed that it is justified to raise funds for environmental project by taxing air travel. This is consistent across the sample among respondent of varying income level and type of airline used. The findings tally with the argument from Brouwer et al. (2008) who suggest that consumers have a growing awareness of environmental issues and are more willing to pay tax to reduce negative impacts and correct for externalities. The findings from this study seem to suggest that the willingness to pay for the tax is higher if earmarked for environmental projects. This result suggests that the APD is an efficient but 
ineffective tax, as it will not significantly reduce consumption but the implied lower elasticities to taxes suggest that increases in the APD is a lead to higher government tax revenue. This needs to be further investigated and the relevant tax elasticities be calculated to further inform this issue. Therefore, unless the tax revenue is used in carbon mitigating projects, the APD is not an effective way of reducing emissions from air travel.

\subsection{Influence on travel behaviour}

The respondents were asked to consider two different scenarios, the first where the APD is expected to rise and the other with APD expected to fall. Surprisingly, most of the traveller strongly agreed that a rise in the APD will not discourage them from travelling as frequently confirming an implied low responsiveness among travellers to changes in the structure of this tax. Only $30.4 \%$ agreed that they will reconsider international outbound trips. These findings are consistent across income levels and type of airlines used. This may be explained by the fact that $45 \%$ of the samples are non-British citizens and therefore, may be traveling to their country of origin to visit friends and families regularly, and are therefore less likely to cut down on travel. $61.1 \%$ state that they are unlikely to cut down on international travel because they were not willing to forgo their holiday. This research hypothesises that if the cost of the ticket rises due to an increase in taxes charges and consumers are not willing to reduce the number of flights, they may be more willing to adjust their behaviour to avoid the taxes. However, consumers seem to be willing to absorb the cost. Only $8.9 \%$ agreed that they will choose short haul destination to avoid paying higher taxes on long haul ones contradicting Tol (2007) to some extent. Tol (2007) states that carbon taxes will lead to long-haul travellers flying to closer destinations. The question which arises is how will consumers finance this increase in taxes?

$27.7 \%$ agree that they will reduce their non-travel expenses which means that the travel budget is unlikely to be affected but that the tax incidence will to some extent fall on businesses, which may not be directly related to the travel industry and have distortionary effects on the British economy. On the other hand, $36.6 \%$ indicate that they will reduce their travel related expenses indicating that a rise in taxes will to some extent lead to a reallocation of the travel budget among the different items of expenditure which is confirmed in Song, Seetaram and Ye (2019). Of these, $45.5 \%$ travelled on full cost airlines and $30.2 \%$ travelled on low cost airlines. The expected fall in expenditure on travel related goods and services depend on the demand elasticities. However, the finding in this study has implications for destinations even more so if higher taxes in the UK lead to a reduction in expenditure at the 
destination, in less developed countries that are reliant on tourism revenue as an engine for economic growth. Only $16.7 \%$ of respondents will consider cutting down on the duration of their trips following an increase in taxes.

On the question on how consumers will behave faced with a fall in taxes, it is interesting to note the asymmetry in the responses. $45.5 \%$ agreed that a fall in taxes will encourage them to travel more, compared to only $30.4 \%$ who will reconsider international travel if taxes are to increase. This suggests that consumers are more responsive to fall in the cost of air travel than they are to increases. The resulting savings from their budget will encourage them to spend more at the destination (53.6\%). 37.5\% would increase their expenditure locally on non-tourism related products. The finding is similar for all income groups and types of airline used. These results may indicate that a fall in taxation will not only benefit the destination but may have positive effect on the British economy too.

\section{SUMMARY AND CONCLUSION}

The aim of this study was to examine British consumers' knowledge, awareness, attitude and reaction to changes in the air passenger duty which in imposed on all outbound air travel from the UK. Data were collected using an online survey. The key findings of this study are that consumers have limited knowledge of the air passenger duty and other taxes that they incur when they take international trip. A significant proportion stated that they did not incur any taxes on their trip when in fact they would have paid for the ADP, VAT in the UK and other taxes at the destinations such as sales tax, bed taxes and so on. In fact, most travellers believe that taxing air travel is justified, and that the revenue received should be used for financing environmental projects. Most respondents stated that an increase in the APD is unlikely to discourage them from travelling. The increase in the cost of travel will encourage approximately one third of the respondents to either spend less on their trip at the destination. This will have consequences as home as well as a fair number stated that the increase will encourage them to cut down on their non-tourism related expenses in the UK. On the other hand, only $45.5 \%$ of travellers agreed that a fall in taxes will encourage them to travel more. The extra saving from a fall in taxes will either be spent at the destination or in the UK. These results are relevant for both the British economy and the economies of destinations as changes in the structure of air taxes will cause consumers to adjust their expenditures. The exact nature and value of the adjustment will depend on respective prices elasticity the computation 
of which is beyond the scope of this study. The findings can be used to develop a larger and more in-depth study on consumer behaviour in travel industry of the UK.

\section{REFERENCES}

- Airportwatch, 2014. Air Passenger Duty [online]. London: Airportwatch. Available from: http://www.airportwatch.org.uk/air-passenger-duty/

- Brouwer, R., Brander, L. and Beukering, P., 2008. 'A convenient truth': air travel passengers' willingness to pay to offset their $\mathrm{CO} 2$ emissions. Climatic Change [online], 90, 299-313.

- Bryman, A., 2012. Social Research Methods. 4th ed. Oxford: Oxford University Press.

- Chang, J., Lu, L. and Hu, S., 2011. Congestion externalities of tourism, Dutch disease and optimal taxation: Macroeconomic Implications. The Economic Record [online], 87 (276), 90-108.

- Dresner, M., 2006. Leisure versus business passengers: Similarities, differences, and implications. Journal of Air transport Management [online]. 12, 28-32.

- Durbarry, R., 2008. Tourism Taxes: Implications for Tourism Demand in the UK. Review of Development Economics [online], 12 (1), 21-36.

- Euromonitor, 2014. Tourism Flows Outbound in the United Kingdom [online]. London: Euromonitor.

- Dwyer, L., Gill, A., \& Seetaram, N. (eds.). 2012. Handbook of research methods in tourism: Quantitative and qualitative approaches. Edward Elgar Publishing

- Finn, M., Elliott-White, M. and Walton, M., 2000. Tourism and Leisure Research Methods: Data Collection, Analysis, And Interpretation. Harlow: Longman

- Fish, M., 1982. Taxing International Tourism in West Africa. Annals of Tourism Research [online], 9, 91-103.

- Forsyth, P., Dwyer, L., Spurr, R. and Pham, T., 2014. The impacts of Australia's departure tax: Tourism versus the economy? Tourism Management [online], 40, 126-136.

- Gooroochurn, N. and Sinclair, T., 2005. Economics of tourism taxation. Evidence from Mauritius. Annals of Tourism research [online], 32 (2), 478-498.

- Jennings, G., 2001. Tourism Research. Milton, Qld.: Wiley Australia.

- Jensen, J. and Wanhill, S., 2002. Tourism's taxing times: value added tax in Europe and Denmark. Tourism Management [online], 23, 67-79.

- Mayor, K. and Tol, R., 2007. The impact of the UK aviation taxon carbon dioxide emissions and visitor numbers. Transport Policy [online], 14, 507-513.

- Millet, J., 1987. The Role of Tourism in Development. Institute of National Affairs [online], 89, 56-58.

- ONS, 2013. Overseas residents' visits, nights and spending in the UK 1980 to 2013 [online]. London: Office of National Statistics.

- PwC, 2013. The Economic Impact of Air Passenger Duty [online]. London: PricewaterhouseCoopers LLP.

- Rhodes, C., 2015. Tourism: statistics and policy [online]. London: House of Commons Library.

- Schipper, Y., Rietveld, P. and Nijkamp, P., 2001. Environmental externalities in air transport markets. Journal of Air Transport Management [online], 7, 169-179.

- Seely, A., 2014. Air Passenger Duty: recent debates \& reform [online]. London: House of Commons Library.

- Seetaram, N., Song, H. and Page, S., 2013. Air Passenger Duty and Outbound Tourism Demand from the United Kingdom. Journal of Travel Research [online], 53 (4), 476-487. 
- Seetaram, N., Song, H., Ye, S., \& Page, S. 2018. Estimating willingness to pay air passenger duty. Annals of Tourism Research, 72, 85-97.

- Sheng, L. and Tsui, Y., 2009. Taxing Tourism: enhancing or reducing welfare? Journal of Sustainable Tourism [online], 17 (5), 627-635.

- Smith, C., 2008. How the weak pound is affecting travelers. The Telegraph [online], 10 December 2008. Available from: http://www.telegraph.co.uk/travel/3702421/SterlingFall-How-the-weak-pound-is-affecting-travellers.html

- Smith, O., 2014. Budget 2014: air tax reform provides boost for holidaymakers. The Telegraph [online], 19 March $2014 . \quad$ Available from: http://www.telegraph.co.uk/finance/budget/10708286/Budget-2014-air-tax-reformprovides-boost-for-holidaymakers.html

- Smyth, M. and Pearce, B., 2008. Air Travel Demand [online]. London: IATA.

- Song, H., Seetaram, N., \& Ye, S. 2019. The effect of tourism taxation on tourists' budget allocation. Journal of destination marketing \& management, 11, 32-39.

- Sue, V. and Ritter, L., 2007. Conducting Online Surveys [online] Los Angeles: Sage Publications.

- Thornton, R., Rodgers, J. and Brookshire, M., 1997. On the interpretation of age-earnings profiles. Journal of Labor Research [online]. 18 (2), 351-365. Tol, R., 2007. The impact of a carbon tax on international tourism. Transportation Research Part D: Transport and Environment [online], 12 (2), 129-142.

- UK Parliament, 2003. Parliamentary Business [online]. London: UK Parliament. Available from:

http://www.publications.parliament.uk/pa/cm200203/cmhansrd/vo030715/text/30715w1 8.htm

- World Tourism Organization, 1998. Tourism Taxation: Striking a fair deal [online]. Madrid: World Tourism Organization. 